\title{
THE ATTITUDE OF LOWER COURTS TO CHANGING PRECEDENTS
}

IN a legal system which places a premium on consistency, precedent presents itself as the backbone of the judicial process. Adherence to precedent is the rule and not the exception. ${ }^{1}$ The substance of this rule is twofold although the dichotomy is not clearly delineated. By stare decisis a court is bound to follow its own previous decisions. And by the very nature of the judicial system, "lower" courts are bound to follow previous rulings of that appellate tribunal which may ultimately approve or reject lower court decisions. These doctrines blend, however, so that when the temper of the appellate court demonstrates a willingness to re-examine established precedents on the purely pragmatic basis of current needs, ${ }^{2}$ and stare decisis becomes "a useful rule but not an inexorable command," 3 the problem as to choice of, and conformance to, precedents presented to the "inferior" tribunals becomes significant.

Currently, this inquiry is posed before the courts of the United States as a consequence of the patent "revolution" within the nation's highest behch. 4 The Court has adopted a "practical" view of stare dccisis, putting that doctrine not in the forefront of, but among, the paraphernalia of decision. The Supreme Court long ago declared that, especially in the field of constitutional law, it was more important for it to be tardily correct than consistent." Historical dissents have become law. ${ }^{6}$ The development of the country accompanied by its ever changing circumstances, the continuous changes among the Court's personnel, and the constant adjustment and modification in what is essentially a trial and error technique have all played havoc with the postulates of the Blackstonians. ${ }^{7}$

"Inferior" judges are obviously mindful of these changes, but their opinions do not consistently evince their awareness. They seem to feel automatically constricted by Supreme Court utterances. Though "some of the decisions were by a divided court, it is not for us to question the correctness of the

1. Cardozo, The Nature of the Judicial Process (1921) 34, 149.

2. Davis, Revolution in the Supreme Court (1940) 166 ATL. Montruly 85, 22; Ballantine, Business Without Precedents (1940) 166 Atr. Montiny 235.

3. Mr. Justice Reed, concurring in Erie R. R. v. Tompkins, 304 U. S. 64, 92 (1938). See Mr. Justice Brandeis, dissenting in Burnet v. Coronado Oil \& Gas Co., 285 U. S. 393, 405 (1932).

4. Hamilton \& Braden, The Special Competence of the Supreme Court (1941) 50 Yale L. J. 1318. Hamilton \& Braden, The Supreme Court Today (1940) 103 NEW REPUBLIC 178; Davis, loc. cit. supra note 2.

5. See Barden v. Northern P. R. R., 154 U. S. 288, 322 (1894); The Passenger Cases, 7 How. 283, 470 (U. S. 1849).

6. Most recent example of a dissent expressly becoming a majority opinion is Sunshine Anthracite Coal Co. v. Adkins, 310 U. S. 381, 397 (1940).

7. Willis, Some Conflicting Decisions of the United States Supreme Court (1927) 13 VA. L. Rev. 155, 278; Sharp, Movement in Supreme Court Adjudication (1933) 46 HaRv. L. Rev. 361, 593, 795. 
rules enunciated" 8 and "though its soundness has been questioned (it) still stands as a flat-footed declaration"9 inasmuch as "the choice is not one for an 'inferior' court" 10 and "ordinarily a lone district judge has nothing to do but obey." 11 Rarely have members of the junior bench dared to defy a Supreme Court decision considered, in good faith, to be doomed or erroneous. ${ }^{12}$ Though occasionally affirmed in this disobedience, the great majority of district, circuit, and state judges, even though confronted with a possibility of over-ruling and vigorous criticism by the higher court ${ }^{13}$ usually do not take the full stride.

Theoretically, perhaps, precedents established by the highest court are conclusive on lower courts and leave to the latter no scope for independent judgment or discretion. ${ }^{14}$ Actually, however, lower courts have not accepted precedents as binding in the "strictest sense." Only a leading case, one established through popular usage, repeated judicial affirmation, and general recognition by approved writers on legal topics, commands the full respect of lower judges. ${ }^{15}$ Other cases have been weakened as precedent because they were the product of a strongly-divided bench, because of the absence or non-participation of some justices, because of hesitancy and doubt in the written opinion, or because of affirmation by an equally-divided Court. ${ }^{16}$ Even more precedents have been rejected through the stratagem of distinguishment; others have been the subject of conscious jadicial oversight.

As a consequence, judicial discretion among "inferior" judges is not so confined and limited as legal theorists would have it. Yet it is by no means so extensive and broad as current decisions demand. It is this discretion which currently needs extension, encouragement, and direction.

8. Bullard v. Comm'r of Int. Rev., 90 F. (2d) 144,150 (C. C. A. 7th, 1937).

9. Ostrom v. Edison, 244 Fed. 228, 236 (D. N. J. 1917).

10. Rothensies v. Cassell, 103 F. (2d) 834,837 (C.C.A. 3d, 1939).

11. Louisville \& N. R. R. v. Western Union Telegraph Co., 218 Fed. 91, 93 (E. D. Ky. 1914). The most recent example is Gold v. C'nited States, 115 F. (2d) 236 (C. C. A. 2d, 1940).

12. Louisville \& N. R. R. v. Western Union Tulegraph Co., 218 Fed. 91, 110 (E. D. Ky. 1914), $a p p$. dismi'd, 242 U. S. 665 (1917), wherein Cochran, J. refused to follow Ex parte Wisner, 203 U. S. 449 (1906) because "it is thoroughly wrong on its merits." Accord: James v. Amarillo City Light \& Water Co., 251 Fed. 337, 345 (N. D. Tex. 1918); Sanders v. Western Union Telegraph Co., 261 Fed. 697, 703 (N. D. Ga. 1919) ; Southwestern Gas \& Electric Co. v. Raines, 238 S. W. 904 (Te: Comm. App. 1922) ; Northern Wisconsin Co-op Pool v. Bekkedal, 182 Wis. 571, 593, 197 N. W. 936, 944 (1924); Ex parte Tigner, 132 S. W. (2d) 8S5, 893 (Tex Cr. App. 1939); and see Investors' Syndicate v. Porter, 52 F. (2d) 1S9, 196 (D. Mont. 1931) (dissenting opinion).

13. Palmer v. Massachusetts, 30S U. S. 79 (1939); United States v. Sprague, 282 U. S. 716, 730 (1931) ("the appellees do not attempt to justify the lower court's action by the reasons it states . ...").

14. Black, Law of Judictal Precedents (1912) 10.

15. Baidwin, The Aurerican Judictary (1914) 59.

16. BLACK, op. cit. supra note $14, \S \S 21,35,43$. 
Such discretion can best be broadened by a readjustment of the attitude of lower courts toward superior tribunals. Traditionally, lower courts have looked to the past, to what the upper court has done. Yet the Supreme Court's current movement necessitates an "inferior" counterpart which can be realized only through a progressive view by judges whose opinions should look beyond what occurred yesterday to what ought to prevail toclay or, at least, to what will prevail tomorrow.

In order for "inferior" judges to provide the prophylactic influence required by the uncertainty which characterizes current decisions, they must realize their own power and assert a more unrestrained rule of precedent.

Lower court judges should not be thought to exist in a judicial world apart from the mundane universe. As members of the bench, they are no different from justices of the Supreme Court. Their judicial problem is intrinsically identical. As members of society, they are constituents of the community, subject to prevailing mores, aware of election returns. Like businessmen they are cognizant of the country's economic strains and stresses, and they are subject to practically the same social pressure as the man in the street. And as members of a trade they have sufficient knowledge of their fellow workers to forecast their movements and to understand each judicial action. So equipped and so situated one might well question whether an inferior court fulfills the requirements of its function by mechanically following decisions known to be contrary to the philosophy of the bench, the needs of society, and the personal prejudices of a controlling majority of the Supreme Court.

Perhaps "inferior" judges should adopt an attitude in selecting precedents somewhat like the critically inquiring approach of most courts to questions of fact. Or more precisely, they might follow the practical, pragmatic view of the incumbent Supreme Court toward stare decisis.

Thus, cases whose foundations have been seriously shaken, even though they remain technically "good law," should not command the respect of the lower courts. A good illustration of the problem is presented by the history of the rule of Tyson \& Brother v. Banton ${ }^{17}$ and Ribnik v. McBrille, ${ }^{18}$ only recently reversed on its face by the Supreme Court. Justice Sutherland, who wrote for the Court in both instances, in deciding that the Ribnik case necessarily followed from the $T y$ son case, seemingly concluded that price regulation in regard to all brokers was prohibited because their business was not "affected with a public interest." Justice Brandeis, however, who dissented in both these cases, spoke for a unanimous court in Tagg Brothers \& Moorehead $v$. United States ${ }^{19}$ two years later and detracted from the

17. 273 U. S. 418 (1927).

18. 277 U. S. 350 (1928).

19. 280 U. S. 420 (1930). 
universal applicability of the Ribnik decision by sustaining Congressional control over stockyard brokers operating in interstate commerce.

A New York statute again appeared before the Court in Neblia $v$. Non York. ${ }^{20}$ In upholding as constitutional an act establishing the store price for a quart bottle of milk, the Court, this time with Justice Roberts delivering the opinion, adopted Justice Holmes' dissent in the Tyson case ${ }^{21}$ and effectively interred the previously-defined doctrine of affectation with a public interest. "The phrase 'affected with a public interest' can, in the nature of things, mean no more than that an industry, for adequate reason, is subject to control for the public good."22 The Tyson and Ribmik cases were not specifically upset but they were placed upon a new footing "upon the basis that the requirements of due process were not met because the laws were found arbitrary in their operation and effect." 23

With their original foundations removed, the Tyson and Ribnik cases remained technically good law. But undoubtedly they persisted only as precarious precedent in the light of the new test of an act's reasonable relation to a proper legislative purpose. Yet no district or circuit court pronounced them dead. Forced to follow the Nobbia decision, they cited it only to append the inevitable "See Tyson ". Banton" or "See Ribnik $v$. McBride."24 One district judge even applied them when dealing with the New Jersey cleaning and dyeing trade ${ }^{25}$ while another approved them in a dictum. ${ }^{26}$

Only one tribunal, the New York Supreme Court, openly admitted that "the Supreme Court adopted a new ruling . . . and that ruling, being in effect a reversal of its earlier decisions, is both controlling and compelling on this court."27 Interestingly enough, Judge Bernstein, who wrote the opinion, was at the time confronted with a re-enactment of the statute struck down in the Tyson case. The Ribnik fact situation recently re-appeared in the Nebraska Supreme Court. ${ }^{28}$ That court, though counsel ably depicted the demise of the 1928 decision, felt bound thereby, for "The Supreme Court

20. 291 U. S. 502 (1934).

21. ". . The notion that a business" is clothed with a public interest and has been devoted to the public use is little more than a fiction intended to beautify what is disagreeable to the sufferers. The truth seems to me to be that, subject to compensation when compensation is due, the legislature may forbid or restrict any business when it has a sufficient force of public opinion behind it." Tyson \& Brother v. Banton, 273 U. S. 418,446 (1927).

22. Nebbia v. New York, 291 U. S. 502, 536 (1934).

23. Ibid.

24. See, for example, Paramount Pictures v. Langer, 23 F. Supp. $\$ 90,895$ (D. N. D. 1938) ; Yankee Network v. F. C. C., 107 F. (2d) 212, 221 (App. D. C. 1939).

25. Kent Stores of N. J. v. Wilentz, 14 F. Supp. 1, 9 (D. N. J. 1936).

26. United States v. Seven Oaks Dairy Co., 10 F. Supp. 995, 1001 (D. Mrass. 1935).

27. Kelly-Sullivan, Inc. v. Moss, 22 N. Y. S. (2d) 491 (Sup. Ct. 1940).

28. State v. Kinney, 293 N. W. 393 (Neb. Sup. Ct. 1940), 27 VA. L. REv. 115, 29 GEo. L. J. 110. 
has not expressly overruled the case of Ribnik $v$. McBride. . . . We cannot logically indulge in speculation." ${ }^{29}$ But counsel's contention was proved to be more than "mere speculation" when the Supreme Court, reversing the timid lower court, held Ribnik $v$. McBride not to be the law of the land. ${ }^{30}$

Similar to precedents like the Tyson and Ribnik cases, which hang in the air, with the ground cut from under, is an ancient, unoverruled decision, ravished by the passage of time and existing in a strange new environment. For an "inferior" judge to grant credence to such a precedent would be to exalt the past for its own sake. Such a decision is Connolly $v$. Union Sewer Pipe Co., ${ }^{31}$ a case in which the equal protection clause of the Fourteenth Amendment was used to overthrow an early Illinois Anti-Trust Act. The act had exempted from its provisions farmers and cattle raisers and Justice Harlan could not find "under what rule of permissible classification" 32 such legislation could be sustained. Within four years this case was placed in doubt by Cox $v$. Texas, ${ }^{33}$ upholding a Texas liquor statute although it expressly did not apply to wines produced from grapes while in the hands of agriculturists. Nor was the doubt resolved in Intcrnational Harvester Co. v. Missonti ${ }^{34}$ where Justice McKenna, the sole dissenter in the Connolly case, upheld another state anti-trust act which cliscriminated between producers and purchasers of commodities. His closing words were "It is said that the statute as construed by the Supreme Court of the State comes within our ruling in Connolly v. Union Sewer Pipe Co., but we do not think so." 35 And two years later the same court, after citing the Connolly case inter alia, stated "We need not pause to review them or the many cases clecided since them explaining the wide discretion a legislature has in the classification of objects of legislation." 36 There thus remained unoverruled a decision which maintained its position of record while government, through a variety of acts, recognized the farmer as an individual apart in an industrial society, supported his co-operative venttres, relieved him from the restrictions of the anti-trust laws, and freed him from taxes. ${ }^{37}$

But lower courts have questioned its status only four times, ${ }^{38}$ twice in federal tribunals which cited it some twenty-five times. Generally clistrict

29. State v. Kinney, 293 N. W. 393, 398 (Neb. Sup. Ct. 1940).

30. Olsen v. Nebraska, 61 Sup. Ct. 862 (U. S. 1941).

31. 184 U. S. 540 (1902).

32. Id. at 564 .

33. 202 U. S. 446 (1906).

34. 234 U. S. 199 (1914).

35. Id. at 215.

36. Chicago, T. H. \& S. E. Ry. v. Anderson, 242 U. S. 283, 285 (1916).

37. The legislation is collected in Tigner v. Texas, 310 U. S. 141, 145-146 (1940).

38. Weed \& Co. v. Lockwood, 266 Fed. 785 (C. C. A. 2d, 1920); Karr v. Baldwin, 57 F. (2d) 252 (N. D. Tex. 1932); Northern Wisconsin Co-op Pool v. Bekkedal, 182 Wis. 571, 197 N. W. 936 (1924) ; Ex parte Tigner, 132 S. W. (2d) 885 (Tex. Cr. App. 1939). 
and circuit courts were not confronted with the problem of its appropriateness, so numerous were other applicable, though different, constitutional decisions available as precedent. Nevertheless, it was still followed as recently as 1933 when the Circuit Court of Appeals for the First Circuit declared unconstitutional a New Hampshire Peddlers and Hawkers Act which exempted vendors of agricultural products and implements. ${ }^{39}$ It remained for two state tribunals to "overrule" the decision themselves," which they did "with due deference to the superior authority of the Supreme Court" 11 because "it may be doubted whether at the present time the holding in Connolly v. Union Sewer Pipe Co. . . . would be followed." 42 This latter pair of decisions paved the path for Justice Frankfurter to deal the mortal blow in Tigner $v$. Texas. ${ }^{43}$

Also to be disparaged as precedent is a time-worn decision which has been chipped away by constant distinguishment and contraction. Into the field of administrative law, the Supreme Court, in 1932, threw the bombshell of Crowell v. Benson, ${ }^{44}$ wherein Chief Justice Hughes established trials de novo for "constitutional" and "jurisdictional" facts. These vague terms, with their conveniently dubious definition, immediately arousing speculation as to their validity, ${ }^{45}$ remain technically untouched today. But, in view of subsequent rulings in this field and the altered personnel of the Court, it is questionable whether they carry their weight in paper.

Four years subsequent to the Crowell decision, the Court affirmed trial de novo, for "constitutional" fact," but in 1939, a newly constituted bench enunciated, through Justice Frankfurter in Rockester Telephone Corp. $\approx$. United States, ${ }^{47}$ criteria for judicial action subsequent to that of any administrative board. Among them was administrative finality, making it incumbent on federal courts to accept the findings of the commissions as conclusive if the administrators had not ignored the clear preponderance of evidence. No mention was made of "constitutional" or "jurisdictional" facts. ${ }^{48}$ The

39. Healy v. Ratta, 67 F. (2d) 554 (C. C. A. 1st, 1933). The Comolly case was also followed in United States v. Armstrong, 265 Fed. 683 (D. Ind. 1920).

40. Northern Wisconsin Co-op Pool v. Belkkedal, 182 Wis. 571, 593, $197 \mathrm{~N}$. W. 936, 944 (1924) ; Ex parte Tigner, 132 S. W. (2d) \&\$5, 893 (Tex. Cr. .Ipp. 1939).

41. Ex parte Tigner, $132 \mathrm{~S}$. W. (2d) 885,893 (Tex. Cr. App. 1939).

42. Northern Wisconsin Co-op Pool v. Bekkedal, 182 Wis. 571, 593, $197 \mathrm{~N}$. W. 936, 944 (1924).

43. 310 U. S. $141,147(1940)$.

44. 285 U. S. 22 (1932).

45. Dickinson, Crowell v. Benson (1932) 80 U. of PA. L. Rev. 1055; Comment (1932) 41 Yale L. J. 1037; Comment (1932) 46 Hanv. L. Rev. 478; (1932) 30 Micr. L. REv. 1312; (1932) 32 COL. L. Rev. 738; (1932) 10 N. Y. U. L. Q. 93.

46. St. Joseph Stockyards Co. v. United States, 298 U. S. 38 (1936).

47. 307 U. S. 125 (1939).

48. This fact has been deemed important. See Hankin, Kcceut Trends in The Decisions of the Supreme Court of the United States (1940) \& Geo. Wisur. L. KEv. $1001,1025$. 
same Court, through the same justice, emphatically affirmed this position on the final opinion day of the 1939 term when it asserted, "It is not for federal courts to supplant the Commission's judgment even in the face of convincing proof that a different result would have been better." 40 During the same term, South Chicago Coal \& Dock Co. v. Bassett, on its facts from the Crowell case, had reflected'a tendency to limit the effect of the decision, when the Chief Justice failed to mention the case even though certiorari had been granted to resolve circuit court conflict in interpretation of the Crowell decision. Thus, Crowell $v$. Benson, despite the fact that previous to the Rochester ruling, trials de novo were granted in three cases, ${ }^{51}$ rests in precipitous proximity to oblivion.

Yet no lower court has "overruled" the Crowell case. "Inferior" judges, occasionally professing uncertainty ${ }^{52}$ as to the meaning of the terms involved, have succeeded in confining it to its facts ${ }^{53}$ so as to alleviate the result of any straight application, but it has been followed at least seven times. ${ }^{54}$ The Circuit Court of Appeals for the First Circuit even extended it to a consideration of the Johnson Act. ${ }^{65}$ In but one instance did the Crozvell case's applicability as precedent appear in great doubt and there it was finally followed by a sharply-divided court. ${ }^{56}$

These three instances provide illustration of the necessity for the exercise of wider but careful discretion by lower courts in adherence to precedent. In each case, members of the junior bench had reason to know the inappropriateness of these unoverruled but mutilated decisions. These same judges, if faced with conflicting precedents in a common law field, one antique, one

49. Railroad Comm. of Texas v. Rowan \& Nichols Oil Co., 310 U. S. 573, 584 (1940).

50. 309 U. S. 251 (1940).

51. Borax Consolidated, Ltd. v. Los Angeles, 296 U. S. 10 (1935) (review of jurisdiction of United States Land Office); United States v. Idaho, 298 U. S. 105 (1936) (review of I. C. C.) and Baltimore \& O. R. R. v. United States, 298 U. S. 349 (1936) (review of I. C. C.).

52. N.L.R.B. v. Cherry Cotton Mills, 98 F. (2d) 444 (C. C. A. 5th, 1938); Metropolitan Sand \& Gravel Corp. v. Lowe, 22 F. Supp. 65 (E. D. N. Y. 1938).

53. See, for example, St. Joseph Stockyards Co. v. United States, 11 F. Supp. 322 (W. D. Mo. 1935).

54. Green v. Crowell, 69 F. (2d) 762 (C. C. A. 5th, 1934); Metropolitan Casualty Ins. Co. v. Hoague, 72 F. (2d) 175 (App. D. C. 1934); Denver Union Stockyard Co. v. United States, 57 F. (2d) 735 (D. Colo. 1932); Wichita Gas Co. v. Public Service Comm., 2 F. Supp. 792 (D. Kan. 1933); Appalachian Elec. Power Co. v. Smith, 4 F. Supp. 6 (W. D. Va. 1933); United States v. International Freighting Corp., 20 F. Supp. 357 (S. D. N. Y. 1937); Metropolitan Sand \& Gravel Corp. v. Lowe, 22 F. Supp. 65 (E. D. N.'Y. 1938).

55. Munoz v. Porto Rico Ry. Light \& Power Co., 83 F. (2d) 262 (C. C. A. 1st, 1936).

56. St. Joseph Stockyards Co. v. United States, 58 F. (2d) 290,295 n. (W. D. Mo. 1932). 
modern, normally follow the later one. In public law, ${ }^{57}$ however, judges exhibit timidity, perhaps because, instead of conflicting precedents, they are faced with one precedent and an opposing modern trend.ss But public law must be expressed in trends lest the pace of social forces leave the judicial machinery far behind.59 When a "superior" court is cognizant of this and moves swiftly, the judicial system's over-all vigor will depend in no small part on "inferior" courts matching the speed of action by expressing greater independence of the dead hand of the past."

This independence, if it is to have a prophylactic rather than a disruptive effect, must be prudently employed. Supposition founded on pure conjecture comports with this problem as inadequately as it does with any other legal analysis. Decision here must be guided by the fair preponderance of the evidence, and the evidence admissible consists of considerations of current social and economic factors, public opinion, recent movements by the appellate tribunal, and the personal philosophies of the appellate judges now sitting. The zone of freedom is bounded by knowledge, not hunch.

To comply with the requirement of knowledge, a lower court judge should today accept as mandatory precedent, for instance, Stcwart Dry Goods Co. v. Lewis ${ }^{61}$ and Valentine v. Great Atlantic \& Pacific Tca Co., ${ }^{62}$ standing for the doctrine that classification for tax purposes according to gross sales is arbitrary and violative of the equal protection clause of the Fourteenth Amendment. These cases continue to bear weight even though the Court has recently indicated its readiness to reconsider them in Minnesota $z$. National Tea $\mathrm{Co}_{0 .}{ }^{63}$ and even though the earlier case received unfarorable

57. Into this field has been adopted the doctrine of stare decisis, a doctrine originally born to the common law. Its application as a controlling consideration in this field has been seriously doubted. See, for example, Llewellyn, The Constitution as as: Institution (1934) 34 CoL. L. Rev. 1, 6, 35.

58. Great Northern Ry. v. Weeks, 297 U. S. 135 (1936), holding that a property tax which did not take into account the financial collapse of 1929 was invalid, is in definite conflict with Nashville, C. \& St. L. Ry. v. Browning, 310 U. S. 362 (1940) which, on the same point, decided the tax was valid since the needs of the state required it. While the former decision is not an antique in point of time, it is out-moded in view of the change in the Court.

59. Hammer v. Dagenhart, 247 U. S. 251 (1918), which held that Congressional regulation of child labor is unconstitutional as an invasion of the powers reserved to the States, ought not to have been controlling even before it was overruled by the Supreme Court in approving the Fair Labor Standards Act. United States v. Darby Lumber Co., 61 S. Ct. 451,458 (U. S. 1941); see Golding, The Industry Committec Provisions of the Fair Labor Standards Aet (1941) 50 YALE L. J. 1141, 1142.

60. "The trial courts would operate out on the front line, where the impzet . . . is first felt." Dowling, Interstate Commerce and State Peaser (1940) 27 VA. L. Rev. 1, 23.

61. 294 U. S. 550 (1935).

62. 299 U. S. 32 (1936).

63. 309 U. S. 551 (1940), 29 GEo. L. J. 373. 
comments, ${ }^{64}$ most of which approved the Cardozo-Brandeis-Stone dissent. ${ }^{06}$ Were the fact situation of either to reappear in a lower court today there could be but one conclusion. The evidence of disapproval is not sufficiently persuasive to sanation independence, for the Court has in no way indicated even a likely result of reconsideration.

While narrowing by the Supreme Court may stifle a precedent, distinguishment which provides a more restricted but, nevertheless, continuing life for a case preserves that case as authority. Thus, the Duplex Printing ${ }^{60}$ and Bedford Cut Stone ${ }^{67}$ decisions, recipients of both commendation and condemnation from Justice Stone in the Apex Hosiery ${ }^{68}$ case have not been specifically overruled. In the latter case, the Court professing to follow the earlier holdings that secondary boycotts in restraint of interstate commerce were in violation of the Sherman Act, actually placed them on a new ground, inserting beneath them a newly-created economic test concerned with market price variation. But when this ruling was coupled with the Norris-LaGuardia Act, $^{69}$ in United States $v$. Hutcheson ${ }^{70}$ the force of the Duplcxt and Bedford cases appears to have seriously deteriorated.

There is extant a belief ${ }^{71}$ that the dissents of Justice Black in the Goncral Talking Pictures ${ }^{72}$ decisions are today law. This belief must be based on the fact that at the time of its original hearing Justice Black was the only new appointee on the Court, and on the further fact that two years later there was decided another patent case ${ }^{73}$ in which all five recent appointees sided with the majority in an opinion similar to Justice Black's dissent. But lower judges have no duty to act in disregard of the Talking Pictures case. Justice Black dissented in an infringement suit concerned with use restrictions. He concurred with a later majority in deciding an action brought by the Government under the Sherman Act for price restrictions. In view of this clear distinction between the cases and despite the pronounced change in the ranks of the Court, the Talking Pictures case is not one to go ignored in the lower courts. There exists no expressed conflict of opinion.

The problem for "inferior" judges is thus posed by the antithetical demands of society for a law that is stable and sure and for a law that is in sufficient

64. See (1935) 35 Cor. L. Rev. 606; (1935) 48 HARv. L. REv. 1434; (1935)

33 Mich. L. Rev. 1278; (1935) 83 U. of PA. L. Rev. 1024.

65. Stewart Dry Goods Co. v. Lewis, 294 U. S. 550, 566 (1935).

66. Duplex Printing Press Co. v. Deering, 254 U. S. 443 (1921).

67. Bedford Cut Stone Co. v. Stone Cutters' Assoc., 274 U. S. 37 (1927).

68. Apex Hosiery Co. v. Leader, 310 U. S. 469 (1940).

69. 47 Stat. 70 (1932), 29 U. S. C. $\$ \S 101,102,103,104$ (1934).

70. 312 U. S. 219 (1941).

71. See Hanilton, The Pattern of Competition (1940) 73, n. 8.

72. General Talking Pictures Corp. v. Western Electric Co., 304 U. S. 175, 183 (1938), reargued and aff'd, 305 U. S. 124, 128 (1938).

73. Ethyl Gasoline Corp. v. United States, 309 U. S. 436 (1940). 
flux to keep apace with current needs. "4 "A few hints, a few suggestions, the rest must be trusted to the feeling of an artist." 75 The attitude adrocated can be simply stated: if the underlying reasons for a precedent are gone, if the precedent has been ignored and isolated in the dim past while competing philosophies have surged ahead, ${ }^{77}$ or if the precedent is adhered to only for face-saving purposes ${ }^{78}$ - then a lower cuurt slould feel free to wield an axe; but if an old precedent has been simultaneously damned and praised without a clear description of its force, ${ }^{70}$ or if the precedent is recent and no disparaging words have been forthcoming ${ }^{89}$ - then a lower court may feel free to pass the task of axe-wielding on to higher authority..$^{\text {s }}$

Progress will appear and conflict be resolved by clearing the vast underbrush of contradictory cases. This could effectively be accomplished within the Supreme Court, but that tribunal seldom expressly repudiates the precedents it now considers inappropriate. Frequently it has been satisfied to evade a decision where direct overruling is aroided ${ }^{82}$ and unmindful of the clarity required when "the sentence of today will make the right and wrong of tomorrow," 83 has passed on that responsibility to the lower courts. This responsibility can be accepted and constructively handled by these courts

74. Spruill, The Effect of an Ozerraling Decision (1940) 18 N. C. L. REv. 199, 202.

75. Carnozo, op. cit. supra note 1,36 .

76. See discussion of Tyson and Rimik cases supro p. 1450 .

77. See discussion of Connolly case supra p. 1452.

78. See discussion of Croucll case supra p. 1453.

79. See discussion of Duplcx Printing and Bedford Cut Stone cases supra p. 1456.

80. See discussion of General Talking Pictures case supra n. 1456.

81. "Inferior" judges should be aware that express overruling, as in Helvering v. Hallock, 309 U. S. 106 (1940), may leave an old decision with yet one final breath. In the Hallock case, Justice Frankfurter, overruling Helvering v. St. Louis Trust Co., 296 U. S. 39 (1935) and Becker v. St. Louis Trust Co., 296 U. S. 48 (1935), said at 119 , "We have not before us interests created or maintained in reliance on those cases." It would appear, therefore, that the St. Louis Trust cases control trusts established between 1935 and 1940. Such a case will probably never arise, however, since the Internal Revenue Bureau has adopted this view of limiting the retroactivity of the Hallock decision. 9 U. S. L. WEEK 2191 (1940).

The lower courts should also perceive the valid fractions of a "partially-averruled" decision. Hendrix v. United States, 219 U. S. 79 (1911) and Jin Fuey Moy v. United States, 254 U. S. 189 (1920) were each expressly overruled in part only in Funl: v. United States, 290 U. S. 371, 387 (1933); yet only in a single case, Heller v. United States, 104 F. (2d) 446 (C. C. A. 4th, 1939), have the valid portions of either of them been cited. They must perceive every movement within the Court. See Bemis Bros. Bag Co. v. Feidelson, 13 F. Supp. 153, 158 (W. D. Tenn. 1934).

82. See Powell, 1939-1940 Supreme Court Decisions on State Taration of Insterstale Commerce (1940) 26 Bull. Nat. TAX Ass'N 23, 25.

83. Cardozo, op. cit. supra note 1 , at 21 . 
by an extinction of the query "What has the Supreme Court done?" and substitution therefor of the query "What reould the Supreme Court do?" The answer to the latter question, necessarily pointing beyond the immedinte, would make apparent the futile rigidity inherent in the formality of precedent and would indicate that "the whole subject-matter of jurisprudence is more plastic, more malleable, the moulds less definitively cast, the bounds of right and wrong less pre-ordained and constant than most of us . . . have been accustomed to believe." 84

For an "inferior" judge to discover and determine disparity between the Court's past profession and present performance, ${ }^{85}$ presenting the reasons why, would be to exert the pressure so patently imperative and to fulfill a duty of active assistance to the court above. ${ }^{88}$ The discord of decision, thus temporarily decreased, could be permanently harmonized upon appeal by the Court. To the litigants before the "inferior" judge there would be effected a saving in court expense, inasmuch as an appeal to reach an inevitable result would not be necessary. If no appeal were taken, there would be established good precedent for the jurisdiction outlawing dubious precedent. To the judge there would come a creative opportunity, ${ }^{87}$ possible political protection, ${ }^{88}$ and freedom from the risk of reversal.

84. Id. at 161. But see Gray, Judicial Precedents (1895) 9 HARv. L. REv. 27.

85. As in every legal proceeding, the facts and nature of the case at bar will determine the action of the judge. In one instance, an "inferior" judge might deem it proper to follow doubtful precedent while expressing grave uncertainty as to its appropriateness. In another instance, he might feel it his duty to disregard the precedent, spelling out his reasons therefor. But in either case the losing party would have sufficient indication to warrant an appeal and the judge would be exercising that careful discretion now so necessary.

86. Thus in Brooks v. Dewar, 9 U. S. L. WeEk 4345 (U. S. 1941) the Supreme Court almost explicitly invited the aid of the lower courts in clarifying a conflict: "The petitioner asserts that the judgment below should be reversed because the suit is one against the United States; because the Secretary of the Interior is an indispensable party, and, because the State court was without power to enjoin a federal officer. He admits that earlier cases in this court are against his contention and relics on others which he says sustain his view. As this Court remarked nearly sixty years ago respecting questions of this kind, they have rarely been free from difficulty and it is not 'an easy matter to reconcile all the decisions of the court in this class of cases.' The statement applies with equal force at this day. We are not disposed to attempt a critique of the authorities. Since the jurisdiction and the procedure of the court below is sustained by decisions of this Court, we are unwilling to have our judgment upon a resolution of asserted conflict touching issues of so grave consequence where, as here, the bill fails to make a case upon the merits." Id. at 4346.

87. Under the rule of Erie R. R. v. Tompkins, 304 U. S. 64 (1938), "inferior" federal courts must undergo this same procedure as regards state court decisions and their availability as precedent. This was done before the Tompkins ruling in United States v. Adams Express Co., 119 Fed. 240, 244 (S. D. Iowa 1902) where the court refused to follow a state decision because "the Iowa Supreme court only decided the case as it did because of stare decisis . . ."

88. One of the factors in the rejection by the Senate of the nomination of Judge John J. Parker as associate justice of the Supreme Court in 1930 was his refusal in 
Still available, it is true, are the judicial implements of distinguishment and omission, conveniences existing as by-products of Anglo-American jurisprudence and soothing devices for the timid jurist. To use them in dealing with these problems is artfully to dodge ${ }^{89}$ rather than to perform the task of the judiciary.

U. MI. W. A. v. Red Jacket Coal \& Coke Co., 18 F. (2d) $\$ 39$ (C. C. A. 4th, 1927) to disregard Hitchman Coal-Coke Co. v. Mitchell, 245 U. S. 229 (1917). 72 Co:sc. R.C7793, 7933, 7936, 8037, 8100, 8439 (1930), collected in Lasdis, Lneos Law (1934) 141.

89. Most recent obvious example of this use is United States v. One Dodge Sedan, 113 F. (2d) 552 (C. C. A. 3d, 1940). 